\title{
ESP/EAP as a Specific Register of Scientific English
}

\author{
Minoo Khamesian \\ Iran Azad University
}

$\mathrm{T}$ he society we are now living in is not the same as the society our antecedents lived in years ago. There is obviously increasing complexity and diversity. Due to this, people are doing their best to improve all the fields possible to help them survive. This includes improving their communication skills.

It is common knowledge that there are different languages in the world. However, just some of them fall into the category of international languages, in other words, languages of wider communication groups, e.g., English, French, Spanish, Russian. However, it is English that is very important nowadays as it is used to publish experimental results, to discuss theories, and to disseminate information in science and technology. And of course people need English to attend universities and colleges of higher education abroad. There are more opportunities for people to get involved in purpose-related communications (scientific, technical and economic) on an international scale.

Therefore, it is not surprising that the learning and teaching of English as a foreign language specifically for the purposes of science and technology has become a prominent area of English language teaching and applied linguistics. As a result, English is gaining popularity as a working tool that satisfies the particular needs in countries where the majority of people have grown up speaking a different language. English has thus become the lingua franca ${ }^{1}$ of the modern world and is systematically used in practically every aspect of life.

Unlike with any other language in the world, non-native speakers of English outnumber the native speakers, which proves how important it is for human interaction on the global scale. Thus, it seems clear why whenever two speakers of different languages meet and try to communicate, English will most probably be the language of choice no matter where the meeting takes place, and as long as they are in need for a third language, there is no doubt which language they will primarily reach for in order to understand and communicate with each other. This has created a demand for good communication skills in English around the world. Millions of people today want to improve their command of English or to ensure that their children achieve a good command of it. To fulfill this requirement it has been recognized that we have to reach beyond the surface manifestations of technical language and to understand the social contexts where the language is used and the purposes to which it is put.

The issue to be concerned is that English courses usually offer focus on general aspects of communication and only a few specialize in certain subject areas such as science or technology. All people speak "normal" English, even chemists or therapists. But they have additional needs; they must also be able to manage "jargon" i.e. the language of specialists. This means that several new words have to be studied, a few new phrases must be introduced which are commonly used and some grammatical features must be studied harder than in "everyday" courses, e.g. the passive voice. 
The notion of a language with singular characteristics began to take root in the sixties early seventies of the $20^{\text {th }}$ century, being associated above all, with the pioneering research of Halliday, Macintosh and Strevens (1964), Jack Ewer and Latorre (1969), John Swales (1971), Henry Widdowson (1978), Louis and Mary Todd Trimble (1978), and the so called Washington School with Larry Selinker (1979).The main aim of these researchers was to design a syllabus that would give a priority to the language that students need in their scientific studies. In order to teach them specific kinds of language and communicative skills needed for particular roles, the focus on needs analysis has become central to determine the specific characteristics of the language which is used for specific rather than general purposes.

What has been mentioned as English for Specific Purposes (ESP) emerged to meet the demands of different "Discourse Communities" as Swales (1990) puts it.

\section{The Origin of ESP}

The history of ESP is not so new as some people may consider. The first examples can be found in the $14^{\text {th }}$ century in a collection of everyday dialogues written for English travellers to France (Howatt 1984). In the 16th century, on the other hand, commercial interests created other phrasebooks and polyglot dictionaries to deal with merchants' needs of learning languages for acquiring some "survival knowledge" for trading. Learning languages, however, has been considered mostly as a matter of prestige and pleasure for the sake of enlightenment and reading literature in their original versions rather than as a requirement to get a new job or an activity that could contribute to the accomplishment of shared objectives. But the nature of English for Specific Purposes, as it is now known, developed in the second half of the $20^{\text {th }}$ century.

It is difficult to establish a particular date for the commencement of ESP in its modern sense. However, as it is widely accepted, several events have contributed to its emergence. Some political, social and economic facts as well as the application of modern linguistic theoretical trends and techniques greatly influenced the growth of ESP.

First of all, the end of the World War II started an era of broad scientific, technical and economic activities on an international scale. This expansion created a unified world, dominated by two powerful forces - technology and commerce - which soon demanded an international language for the exchange of ideas and goods. The university community, scientists, technicians, economists were in need of a common language in order to export and import knowledge and technology. For well-known reasons especially due to economic and cultural influence of the UK and the USA, as well as their status as global superpower countries, this very responsible role has been taken on by the English language which has now become one of the main means of international communication.

In a global economy where reliance on technological growth and progress is greater than ever, the power of scientific discourse is conceivably greater as well. This expansion of scientific and technical English gave rise to what is known as English for Science and Technology (EST), also called English for Academic Purposes (EAP), which can be considered as the building block in the continuum of ESP and as broadly accepted, its most fruitful branch. 
In an interesting retrospective view of this phenomenon since its outset, Swales (1988) claims that the article "Some measurable characteristics of Modern Scientific Prose" by Barber (1962) followed by Herbert and others can be considered as a starting point. Moreover, scholars such as Robinson (1980), and Howatt (1984), indicate that ESP began in 1969 with the first conference on "Languages for Special Purposes," although both recognize that the preliminary work had been done during the decade before.

As a result, linguistics started moving away (to a certain extent) from focus on grammar as the pivotal component of language abilities to a consideration of how language is used in different contexts of communication. It was realized that if language varies from situation to situation, it should be possible to determine characteristic features of specific situations and make those features the core of learners' courses (Hutchinson \& Waters 1987; Gasparian 1998; Richards 2001).

The view advanced the point that the English needed by specific group of learners could be identified by analysing the linguistic characteristics of a specialist area of work or study. "Tell me what you need English for and I will tell you the English that you need" (Hutchinson \& Waters 1987:8).

In this connection Widdowson's works are presumably the first to be mentioned. They undoubtedly paved a way for the paramount idea that language, in spite of its systematic character, is provided with the ability to display different specific features in different spheres of its use. His major finding was that "the language we speak and write varies considerably, and in a number of ways from one context to another". Since language varies depending on the situation of use, features of specific situations will be detected and they will make the basis of the learner's course/textbook. Therefore the direction of study went from the learner to the language and not vice versa (Widdowson 1978; 1979).

Last but not least, new developments in educational psychology regarding teaching and learning emphasized the learners' goals and their attitudes towards the language they chose to learn. Therefore, focus on the learners' needs became equally paramount as the methods employed to disseminate linguistic knowledge.

Learners were seen to have different needs and goals, which would have an important influence on their motivation to learn and, consequently, on the efficacy of their learning. The main idea expressed in related publications was that: when we are concerned with communicative language teaching we have to proceed from the assumption that people merely pursue the practice of these or those syntactic patterns but they always aim at fulfilling certain communicative functions. Therefore, before starting to teach a foreign language the teacher is obliged to have a distinct idea about the language the learners need to be taught. In other words, to be able to learn and use a foreign language as a medium of effective international communication the learner must be acquainted with the basic language of his profession. As far as the methods of teaching ESP is concerned, it should be added that methodologists have seen teacher-oriented language teaching insufficient and outdated, as it is now beyond suspicion that involving the learners in active work in class makes language teaching more effective and provides for the teacher an opportunity to avoid the danger of indulging in excessive talking in class. As 
a result of learner-centeredness, the learners actually take an active part in the teaching themselves (Hutchinson \& Waters 1987; Gasparian 1998; Fahady 2001).

\section{The Development of ESP}

Since its early beginning in the 1960s, ESP has undergone five main phases of development: (a) Register Analysis, (b) Rhetorical or Discourse Analysis, (c) Target Language Use (TLU) Situation Analysis, (d) Skills-Centered Approach and (e) LearningCentered Approach.

Register analysis took place mainly in the 1960s and early 1970s, and was associated in particular with the works of Strevens (Halliday, Mclntosh and Strevens 1964), Ewer (Ewer and Latorre 1969) and Swales (1971). It was based on the principle that the English needed in one scientific field comprised a specific register different from those of other fields of science or General English. Register analysis attempted to identify the grammatical and lexical features of different scientific registers. In this phase, ESP focused on language at the sentence level. Nevertheless, with the development of discourse analysis, ESP entered a second phase of development typically known as the phase of Rhetorical or Discourse Analysis. The basic hypothesis of this stage was concisely described by Allen and Widdowson (1974) who took the view that the difficulties encountered by the students arose from an unfamiliarity with English use rather than from a defective knowledge of the system of English. Allen and Widdowson (1974) argued that ESP students' needs could best be met by an ESP course which developed the knowledge of how sentences were used in the performance of different communicative acts. The implicit assumption of Rhetorical Discourse Analysis is that the rhetorical patterns of text organization differs significantly between specialist areas of use. However, this point was never very clearly examined (Swales 1985), and indeed paradoxically, the results of the research into the discourse of subject-specific academic texts were also used to make observations about discourse in general (Widdowson 1978).

The increasing interest in communicative language teaching as well as the development of communicative syllabi led to the emergence of the third phase of ESP: Target Language Use (TLU) Situation Analysis. TLU Situation Analysis aimed at establishing procedures for relating language analysis more closely to learners' reasons for learning. ESP courses designed in this phase proceeded first by an identification of the target situation and then by a rigorous analysis of that situation. The identified features then formed the syllabus of the ESP course. Such a process was usually known as Needs Analysis. However, Chambers (1980) preferred to use the term Target Situation Analysis, as it was a more accurate description of the process concerned. The most complete explanation of TLU Analysis was perhaps the system set out in "Communicative Syllabus Design" by Munby (1978).

The fourth stage of ESP development known as Skills-Centered Approach, was an attempt to look below the surface and to consider not the language itself but the thinking processes that underlie language use. The principal idea behind the Skills-Centered Approach was that common reasoning and interpretation processes underlay all language use which made it possible for the students to extract meaning from discourse regardless 
of the surface linguistic forms. The implied assumption in this approach was that students did not need to focus closely on the surface forms of the language; they rather needed to focus on the underlying interpretive strategies, which enabled them to deal with the surface forms. As such, a focus on specific subject registers was unnecessary in this approach because the underlying processes were not specific to any subject register (Chitravelu1980; Grellet 1981; Nuttall 1982; Alderson and Urquhart 1984).

The fifth phase of ESP which attempted to overcome the shortcomings of its preceding phases was Learning-Centered Approach. Proponents of this approach argued that the four preceding phases of ESP were all flawed in that they were all based on descriptions of language use whereas a truly valid approach to ESP must be based on an understanding of the processes of language learning. In fact, the fifth phase of ESP is concerned with the question of what it really means to know a language and it also takes into account the fact that different students learn in different ways.

We have to hasten to add that research in applied linguistics has soon shown the affinity between the intra and extralinguistic levels with research on Genre Analysis (Swales 1980; 1981; 1984 and 1986). Thus, the language used in the professions has moved from being characterized in terms of syntactic or lexical choices to characters of the textual presentation and formulaic requirements of the different contexts. Later on and as a further development of this trend, Swales (1990) called for more attention to the communicative purpose of the communicative event. And even Bhatia (1997) went further by insisting on taking the purpose as the key characteristic feature of genre.

Therefore, Genre Analysis has become more a matter of extensive text-in-context inquiry than straightforward textual or transcriptal scrutiny (Askehave and Swales 2001). However, all phases have played important roles in performing different approaches to ESP and also EAP as a movement within it.

\section{Characteristics and Claims of ESP/EAP}

EAP as a branch of ESP is basically defined as the teaching of English with the specific purpose of helping learners to study, conduct research or teach in English. It can also be considered to be ESP as the features allocated to it by Robinson (1991) are usually thought of as being key features to ESP courses. (Although some characteristic features are controversial, which are further elaborated on in this article.)

Firstly, ESP is goal directed - the students are not learning the English language for the sake of it, but because they need to use English. EAP students are usually current higher education students or they are hoping to go on to higher education after their EAP course. They need to learn English in order to succeed in their academic careers.

Secondly, ESP courses are based on a needs analysis, which aims to specify as closely as possible exactly what it is that students have to do through the medium of English. One important feature of EAP courses is the close attention that is paid to students' aims and what they plan to study. The first stage in any EAP and ESP course is to find out exactly why the students are learning English and therefore what language and skills they will need. Often there is a very clearly specified period for the course. Most EAP students are doing fixed term courses in preparation for an academic course. 
ESP learners tend to be adults rather than children. Most EAP students are over 18 and they will have made a difficult decision to study in an English medium university. Students may need specialist language, but this is not necessarily so. It is the activities that the students will want to engage in that defines the course. As with all ESP, an EAP lecturer would not take a text and say, "What can I do with this?" The starting point is always, "What will my students need to do with this text and how can I help them to do it?"

In some cases, a very high level of proficiency is not required, as long as the students can succeed in their aims. Students need to be able to get good marks for assignments. Our job as EAP lecturers is to find ways to enable them to do this - getting their present tenses correct may not be as important as the overall structure of the essay.

Also a distinction has been made between English for General Academic Purposes (EGAP) and English for Specific Academic Purposes (ESAP). The former refers to the teaching of the skills and language that are common to all disciplines; whereas the latter deals with the teaching of the features that differentiate one discipline from others (Blue 1988a).

There are nearly as many definitions of ESP/EAP as the number of scholars who have attempted to define it. To pave the way, it is better to have a brief look at some definitions and explanations by some specialists in this field.

ESP in its early age was first known as EST (English for Science and Technology). The pioneers of this teaching approach like Ewer and Latorre, Swales, Slinker and Trimble were to be considered as revolutionary figures in linguistics. They opposed traditional linguists who were focusing on describing the features of language; whereas the problem with language was to make it flexible to be used in all settings communicatively. This new perspective of the language could be seen as the only way to help facing the demands of "a Brave New World" (Hutchinson \& Waters 1987:6), the world that suddenly emerged bringing about new challenges especially on the level of study.

ESP had already been used as far back as 1964 by Halliday, McIntosh and Strevens referring to the language varieties typical of a professional activity. The recognition of those varieties brought about many attempts in language teaching to make a deliberate choice of which variety of language is most relevant to particular groups of learners, e.g. English for Science and Technology.

Mackay and Mountford (1978:2) defined ESP as the teaching of English for a "clearly utilitarian purpose". The purpose they refer to is defined by the needs of the learners, which could be academic, occupational, or scientific. These needs in turn determine the content of the ESP curriculum to be taught and learned. They also defined ESP and the "special language" that takes place in specific settings by certain participants and claimed that those participants are usually mature as adults, "highly conscious" of the reasons to achieve English proficiency in the very field of their specialization. Undoubtedly, adults make use of the specialized language in authentic situations because the activities of their specialization have obliged to use the appropriate ESP.

In 1980 Strevens offered the following working definition for ESP and outlined five analytical stages for determining a particular ESP requirement and designing an appro- 
priate course to meet the requirement. He defined ESP as: "ESP entails the provision of English language instruction (i) devised to meet the learner's particular needs; (ii) related in themes and topics to designated occupations or areas of study; (iii) selective (i.e. 'not general') as to language content; (iv) where indicated, restricted as to the language 'skills' included" (1980:108-109).

Stage One involves a needs analysis, based on information provided by the ESP training stakeholders such as learners, sponsors or clients, and other interested parties. Stage Two involves a content analysis, based on the field or discipline in question. In Stage Three, the practitioner determines whether the training needs fall under the EAP or the EOP (English for Occupational Purposes - the other main division of ESP) side of the ESP umbrella. In Stage Four it is further determined whether the training will precede, follow, or be concurrent with content specific training. Regarding Stage Four, Strevens notes that ESP learners who are already established in their professions are likely to be more motivated, mature, and demanding. Finally, in Stage Five, the practitioner prepares a targeted syllabus and appropriate training materials.

For Strevens, the fundamental principle of ESP is that it "is based on a close analysis of the learner's needs". He offers several assumptions regarding ESP which are: time and effort are focused exclusively on learners' needs; mastery of the target material takes less time; ESP learners are more motivated than learners of general English; both learners and teachers are more satisfied with the results; ESP is more cost-effective.

Regarding methods and materials, Strevens mentions notional/ functional, and communicative approaches as being most relevant to ESP. However, he states that ESP is not applied to any particular method, technique, or material. In fact, he views the "freedom to innovate" as being one of the "major attractions" of ESP (1980:120).

Hutchinson and Waters defined ESP as "an approach to language teaching in which all decisions as to content and method are based on the learner's reason for learning" (1987:19). They believe that lacks are what come to determine curriculum not needs since what we are really interested in is the gap between the target proficiency and the present proficiency of the learners. In other words, ESP aims to empower a group of people with specific needs, disregarding if for academic, professional or personal issues. The whole course is tailor-made, so that the focus of the teaching content and method varies according to each field of interest.

On the other hand, Strevens (1988) defined ESP by making a distinction between its absolute and its variable characteristics (although he later changed his belief). He considered the following as absolute characteristics of ESP:

- designed to meet specified needs of the learner;

- related in content (i.e. themes and topics) to particular disciplines, occupations and activities;

- centered on the language appropriate for those activities in syntax, lexis, discourse and semantics;

According to Strevens (1988) the variable characteristics of ESP may be:

- restriction to the language skills to be learned (reading only);

- use of no teaching methodology. 
Robinson (1991) defines ESP on the basis of two criteria:

1. ESP is normally "goal-directed";

2. ESP courses develop from a needs analysis which aims to specify what exactly it is that students have to do through the medium of English, and from a number of characteristics which explain that ESP courses are generally constrained by a limited period of time in which their objectives have to be achieved and taught to adults in homogeneous classes in terms of the work or specialist studies.

Strevens' definition is in line with the definition provided by the linguistic school of Professor Akhmanova (1996) that ESP as a variety (register) of English can be featurized by: 1) a particular conceptual orientation and 2) a set of linguistic features in accordance with the concept different from, and less diversified comparing those of typical every day communication. In other words ESP is not treated as a mere methodology but is discussed from a virtually philological theoretical point of view, that is to say, it belongs to the sphere of functional stylistics. ${ }^{2}$

Gasparian (1998) in her explanation of ESP further elaborates: "When what we are concerned with is communicative language teaching, we have to proceed from the assumption that whenever language is used people do not merely pursue the purpose of practicing these or those syntactic patterns but always aim at fulfilling certain communicative functions. It follows that before setting out to teach a foreign language a teacher must always have a clear-cut idea about what variety of the language her learners need to be taught" (2002). She adds that language, being an integral compact system, can have great differences and peculiarities in different fields of its application, though. Respectively, the real and sensible results of learning could be achieved if the peculiarities of different professional languages are taken into consideration. And on this basis, appropriate curricula are created. A student who learns a foreign language obviously, sooner or later, faces the tasks of; consulting professional literature, dialogueing and discussing over various professional issues, writing scientific abstracts and articles, lecturing in the foreign language, participating in international conferences, etc. The paramount objective for the learner could be mastering the variant of the language that would serve his professional purposes and enable him to communicate with the worldwide scientific thinking.

The word specific in the term ESP focuses on the purpose of the learner (LearnerOriented Teaching). It does not imply the creation of a "Specific Language", but the principles of the choice of certain linguistic means. ESP is laid over human natural language which undergoes changes based on (more or less) restrictions of the applied linguistic means. Thus, proficiency in the varieties of English and the general extra-linguistic knowledge enables the learner to avoid frequent misunderstandings while communicating, and accelerates mutual understanding. In other words, the specific varieties of language play the role of a so-called "Shared Code" between the interlocutors.

Dudley-Evans \& St. John (1998) who prefer to call ESP "an attitude of mind" offer a modified definition and express their revised view on the essence of ESP based on absolute and variable characteristics. According to them the absolute characteristics are: 
- ESP meets the learner's specific needs;

- ESP makes use of the underlying methodology and activities of the disciplines it serves;

- ESP is centered on the language (grammar, lexis, and register) skills, discourse, and genres appropriate for these activities

They consider the following as variable characteristics:

- ESP may be related or designed for specific disciplines;

- ESP may use, in specific teaching situations, a different methodology;

- ESP is likely to be designed for adult learners;

- ESP is generally designed for intermediate and advanced learners.

It is obvious that Dudley-Evans and St. John (1998) are not considering Strevens' absolute characteristic of ESP being in contrast with General English. They have also added more variable characteristics asserting that it is not necessary for ESP to be related to a specific discipline. Furthermore, ESP is likely to be used with adult learners although it could be used with young adults in a secondary school setting. The range of ESP has been extended and become more flexible in the latter modified description.

Anthony (1997) notes that, it is not clear where ESP courses end and general English courses begin; numerous non-specialist EGP (English for General Purposes) instructors use an ESP approach in that their syllabi are based on the analysis of learner needs and their own personal specialist knowledge of using English for real communication. Aside from the rough separation at the definition level between ESP and EGP there is an overlapping connection and proportion between them. In order to clarify their relation Widdowson (1983) establishes distinctive features of ESP and EGP. The most important EGP features are:

1. the focus is often on education;

2. as the learners' future needs are impossible to predict, the course content is more difficult to select;

3. due to the above point it is important for the content in the syllabus to have a high surrender value.

The most relevant ESP features are:

1. the focus is on training;

2. as English is intended to be used in specific vocational contexts, the selection of the appropriate content is easier;

3. it is important for the content in the syllabus to have a high surrender value, most relevant to the vocational context;

4. the aim may be to create a restricted English competence.

The surrender value stands for the overall utility (value) of the English taught by a specific course, the higher the surrender value, the greater the utility of the English taught. These distinctive features reveal the true nature of EGP and ESP.

\section{On the Linguostylistic Method of Analysis}

ESP as a variety of English can be investigated and analysed through the method of linguostylistic analysis (Akhmanova 1972). In the case of this practice, that is, employ- 
ing stylistic norms for the study of a text, it is a convention that all the intricacies, tools, rules and terms of the discipline of Stylistics are applied to the text to be examined. The method deals mainly with two interdependent tasks: a) investigation of special language media which by their ontological features secure the desirable effect of the utterance and b) investigation of certain types of texts (discourses) which due to the choice and arrangement of language means are distinguished by the pragmatic aspect of communication. This method of analysis enables to study any text in great detail, observing what the parts are, and saying what function they perform in the context of the passage. It is, in other words, like taking a car-engine to pieces, looking at each component in detail, then observing its function as the whole engine starts working.

In other words, the linguostylistic method of analysis deals not only with tropes and figures of speech, i.e. stylistic devices proper, but also concerns itself with the study of ultimate units of language from the point of view of denotations and connotations (those additional properties of linguistic units which are superimposed on the semantic content proper).

Otherwise stated, this approach is aimed at investigating a text on two levels: the semantic level and the metasemiotic level. On the semantic level the analysis presupposes the unity of form and content and includes the study of the linguistic units in their direct, nominative meanings. On the other hand, on the metasemiotic level the same linguistic units are studied from the point of view of their functioning in the given context.

The two levels, though different, cannot actually be separated from each other, as there is a constant interchange and interplay between them (Galperin 1971; Akhmanova 1978; Gasparian 2002).

\section{Conclusion}

As the demand for developing a curriculum to meet the students' career needs grows, ESP has been playing an increasingly important role in facilitating students' preparation for professional requirements, training and study. As has been mentioned above, there are different attitudes towards ESP/EAP, but what is notable here is that they all see needs analysis as the common core of ESP, since in ESP courses learner-centered approach is the cornerstone. Its importance lies in the fact that through conducting a needs analysis exercise, curricula-designers can learn two fundamental things: 1) what general and specific language proficiency learners have, and 2) what general and specific language proficiency learners need to acquire (Hutchinson \& Waters 1987; West 1994; Gasparyan 1998; Dudley-Evans \& St Johns 1998; Cook 2003; Busturkmen 2006).

Most ESP/EAP definitions distinguish three themes: the nature of language to be taught and used, the learners, and the settings in which the other two would occur. These three aspects of ESP are very much connected together. ESP is the teaching of specific English (specialized discourse) to learners (adults), who will use it, in a particular setting (business, engineering, medical field, science, etc.) in order to realize a practical purpose.

ESP is considered as a goal directed to a certain kind of language; therefore, the students are not learning the English language for its own sake, but because they are 
enforced by a certain motivation to utilize it in the workplace. Consequently, ESP focuses on developing communicative competence in a specific field (aviation, business, technology, etc).

What ESP specialists seem not to agree upon is what type of language should be taught (vocabulary, register, jargon, etc.) and how to teach it (in context with content knowledge, communicatively, collaboratively, etc.). However, even though there is disagreement and discrepancy among ESP scholars, it is important to note that their many definitions are unequivocally linked to how ESP has developed since it was first spoken of in the 1960s.

While agreeing in varying degrees, these scholars have either explicitly or implicitly acknowledged that any ESP courses should, at the very first place, cater to the target learners' specific needs (either academic or professional). They should be content-relevant to the learners' particular disciplines, occupations and activities (i.e. to the target situation). Also, the language and skills should mirror authentic use by the target community (e.g. the community of doctors or of mechanical engineering students). Ultimately, these considerations of content, language and skills are (and should be) aimed at equipping learners with the necessary knowledge to perform effectively in the target community.

\section{Notes:}

1. Lingua franca literally means Frankish language, that is the language of the Franks, the name that Arabic people used for all Europeans. It originated in the Mediterranean ports in the Middle Ages amongst traders and crusaders of different language backgrounds and it was composed mostly of the Italian language with numerous French, Greek, Persian, Spanish and Arabic words. It was used for communication as a diplomatic language in the Middle East, and the term has since become common for any language used by speakers of various different languages in order to communicate with each other (Richards et al. 1996).

2. Functional Stylistics is a branch of Linguistic Stylistics that investigates functional styles, i.e. special sublanguages or varieties of the national language such as scientific, colloquial, business, public and so on.

\section{References:}

1. Akhmanova, O.S. (1972) Linguostylistics. Thoery and Method. Moscow: MGU,

2. Akhmanova, O. \& Idzelis, R. (1978) What is the English We Use. Moscow: MGU.

3. Allen, J. \& Widdowson, H.G. (1979) Teaching the Communicative Use of English. // The Communicative Approach to Language Teaching. / Ed. by C. Brumfit \& K.Johnson. Oxford: Oxford University Press.

4. Askehave, I. \& Swales J.M. (2001) Genre Identification and Communicative Purpose: a Problem and a Possible Solution. // Applied Linguistics, Vol. 23 (2). 
5. Basturkmen, H. (2006) Ideas and Options in English for Specific Purposes. New Jersey: Lawrence Erlbaum Associates, Inc.

6. Bhatia, V.K. (1997) Genre-Mixing in Academic Introductions. // English for Specific Purposes, Vol.16 (3).

7. Blue, G. (1988a) Individualising Academic Writing Tuition. // Developments in ESP: A multi-disciplinary approach. / Ed. by Dudly-Evans, T. \& St John, M.J. Cambridge: Cambridge University Press.

8. Chambers, F. (1980) A Re-evaluation of Needs Analysis in ESP. // ESP Journal. Vol. 1 (1).

9. Dudley-Evans, T., \& St John, M.J. (1998) Developments in English for Specific Purposes: A Multi-disciplinary Approach. Cambridge: Cambridge University Press.

10. Cook, G. (2003) Applied Linguistics. Oxford: Oxford University Press.

11. Ewer, J.R. \& Latorre, G. (1969) A Course in Basic Scientific English. London: Longman.

12. Grellet, F. (1981) Developing Reading Skills. Cambridge: Cambridge University Press.

13. Farhady, H. (2001). On the specificity of ESP. $<$ www.aua.am/.../6\%200n\%20the\%20specificity\%20ESP.pdf. $>$

14. Galperin, I.R. (1971). Stylistics. Moscow: Progress.

15. Gasparian, S. (July 1998) ESP as an Object of Learner-oriented Teaching. // Didaktic und Methodic des Fremdsprachenunterrichts. Heft I, Bonn.

16. Gasparian, S. \& Knyazian, A. (2002) Academic English for Linguists. Yerevan: Lusakn.

17. Hutchinson, T. \& Waters, A. (1987) English for Specific Purposes: A Learning Centered Approach. Cambridge: Cambridge University Press.

18. Mackay, R. \& Mountford, A. (Eds.) (1978) English for Specific Purposes. London: Longman.

19. Munby, J. (1978) Communicative Syllabus Design. Cambridge: Cambridge University Press.

20. Nuttal, C. (1982) Teaching Reading skills in a foreign language. Oxford: Heinemann.

21. Robinson, P. (1980) ESP (English for Specific Purposes). New York: Pergamon.

22. Robinson, P. (1991) ESP Today: A Practitioner's Guide. New York: Prentice Hall.

23. Selinker, L.; Tarone, E. \& Hanzeli, V. (Eds.) (1981). English for Academic and Technical Purposes: Studies in Honor of Louis Trimble. London: Newbury House.

24. Strevens, P. (1988). ESP after Twenty Years: A Re-appraisal. // ESP: State of the Art. / Ed. by M. Tickoo. SEAMEO Regional Language Centre.

25. Swales, J. (1971) Writing Scientific English, a Textbook of English as a Foreign Language for Students of Physical and Engineering Sciences. London: Nelson.

26. Swales, J. (1985) Episodes in ESP. Hemel Hempstead: Prentice Hall International.

27. Swales, J. (1990) Genre Analysis: English in Academic and Research Settings. Cambridge: Cambridge University Press.

28. Widdowson, H.G. \& Allen, J.P.B. (1974) English in Physical Science. Oxford: Oxford University Press. 


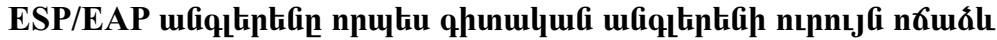

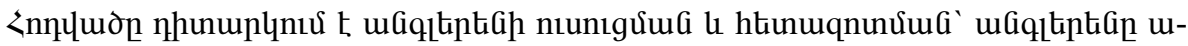

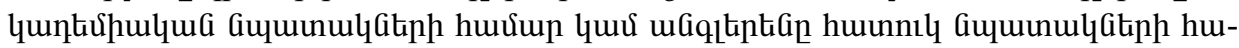

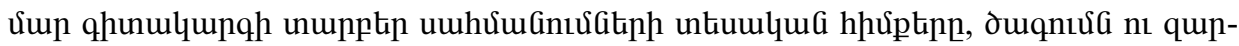

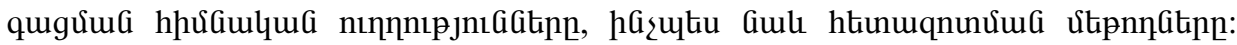

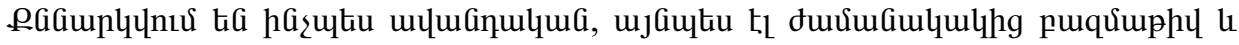
puquiuqua ununtigntúatip: 